\title{
JUDICIAL INTERPRETATION OF COLLECTIVE BARGAINING AGREEMENTS: THE DANGER INHERENT IN THE DETERMINATION OF ARBITRABILITY
}

In 1932, the United States Congress enacted the Norris-LaGuardia Act, which prohibited federal judges from granting injunctive relief in any case arising out of a labor dispute. ${ }^{1}$ The stated purpose for the Act's prohibition was to ensure that the individual employee would be free from restraint or coercion by his employer in clroosing representatives to negotiate the terms and conditions of his employment. ${ }^{2}$ Congress passed. this Act to counteract the federal judiciary's demonstrated partiality toward employers. ${ }^{3}$ The statute achieved the desired effect of impeding employers' easy access to mjunctive relief $\mathrm{m}$ a federal forum; however, it also had the unintended

1. See Norris-LaGuardia Act $\$ 4,47$ Stal. 70 (1932) (codified at 29 U.S.C. $\$ 104$ (1976)). The statute provides: "No Court of the United States shall have jurisdiction to issue any restraining order or temporary or permanent injunction in any case involving or growing out of any labor dispute ...." "Labor dispute" is defined in section 13(c) of the Act as "any controversy concerning terms or conditions of employment, or concerning the association or representation of persons in negotiating, fixing, maintaining, changing, or seeking to arrange terms or conditions of employment, regardless of whether or not the disputants stand in the proximate relation of employer and employee." 29 U.S.C. \& 113(c) (1976). Several cases apply a judicial gloss to this definition of "labor dispute." See, eg., Columbia River Packers Ass'n v. Hinton, 315 U.S. 143, 145-47 (1942); Milk Wagon Drivers' Union, Local No. 753 v. Lake Valley Farm Prods., Inc., 311 U.S. 91, 96-97, 99-100 (1938); New Negro Alliance v. Sanitary Grocery Co., 303 U.S. 552, 559-62 (1938). Other cases discuss the necessity of an employer/employee relationship. See, e.g., Converse v. Highway Constr. Co., 107 F.2d 127, 131 (6th Cir. 1939). But see Green v. Obergfell, 121 F.2d 46, 50 (D.C. Cir. 1941).

2. Section 2 of the Norris-LaGuardia Act, 29 U.S.C. $\& 102$ (1976), outlines the public policy of the United States:

Whereas under prevailing economic conditions, developed with the aid of governinental authority for owners of property to organize in the corporate and other forms of owner-ship association, the individual unorganized worker is commonly helpless to exercise actual liberty of contract and to protect his freedom of labor, and thereby to obtain acceptable terms and conditions of einployment, wherefore, though he should be free to decline to associate with his fellows, it is necessary that be have full freedom of association, self-organization, and designation of representatives of his own choosing, to negotiate the terms and conditions of his enployment, and that be shall be free from the interference, restraint, or coercion of employers of labor, or their agents, in the designation of such representatives or in self-organization or in other concerted activities for the purpose of collective bargaining or other nutual aid or protection; therefore, the following definitions of, and limitations upon, the jurisdiction and authority of the courts of the United States are hereby enacted.

3. See 75 Cong. Rec. 4915 (1932) (statement of Sen. Wagner) (purpose of the Act is to ensure that government, particularly the courts, is neutral in labor disputes). 
effect of increasing the frequency with which strikes occurred.4 Consequently, Congress reintroduced a role for the judiciary in labor dispute settlement in 1947, when it passed the Taft-Hartley Act. ${ }^{5}$ Under the provisions of section 301(a) of the Taft-Hartley Act, federal courts were given jurisdiction over suits involving breaches of collective bargaining agreements. ${ }^{6}$

In the years following the passage of the Taft-Hartley Act, the federal courts struggled to reconcile the apparent conflict in congressional policy between the Taft-Hartley Act, which granted courts the authority to settle disputes over collective bargaining agreenent violations, and the Norris-LaGuardia Act, which deprived the courts of what is often the only effective inechanism for resolving such disputes-the power to grant injunctive rehef. The Supreme Court of the United States has handed down a series of decisions in an effort to reconcile the two statutes, but the result has been an unclear directive to the lower federal courts. The Court has repeatedly admonished the lower federal courts that, when confronted with a collective bargaining agreement containing a nandatory arbitration clause, they should not usurp the arbitrator's function by looking to the merits of the dispute underlying the request for injunctive rehef. ${ }^{7}$ Yet, by making the determination of "arbitrability"s a prerequisite to the granting of injunctive relief, the Supreme Court has opened the door for encroachment upon the arbitrator's role and upon the parties' freedom to contract for an exclusive method of dispute settlement.

This note outlines the steps the Suprene Court has taken in reconciling Taft-Hartley with Norris-LaGuardia that have led to the shift in emphasis away fron consideration of equitable standards for injunctive rehef and nistead toward consideration of whether the dispute is arbitrable. ${ }^{9}$ Using United Auto Workers v. Dana Corp. ${ }^{10}$ as

4. Shank, Boys Markets Injunctions: The Continuing Clash Between Norris-LaGuardia and Tafi-Hariley, 35 Sw. L.J. 899, 899 (1981).

5. Section 301(a) of the Labor Management Relations Act of 1947, 61 Stat. 156 [TaftHartley Act], is codified at 29 U.S.C. \& 185(a) (1976).

6. Section 301(a) provides:

Suits for violation of contracts between an employer and a labor organization representing employees in an industry affecting commerce as defined in this chapter, or between any such labor organizations, may be brought in any district court of the United States having jurisdiction of the parties, without respect to the amount in controversy or without regard to the citizenship of the parties.

29 U.S.C. \& 185(a) (1976).

7. See, e.g., United Steelworkers v. American Mfg. Co., 363 U.S. 564, 567-68 (1960).

8. See generally Boys Markets, Inc. v. Retail Clerks Union, Local 770, 398 U.S. 235 (1970).

9. See infra Section I.

10. 679 F.2d 634 (6th Cir. 1982), reh'g en banc granted and opinion vacated, id. at 654 (Aug. 12, 1982). 
an example, this note examines the manner in which the concentration on arbitrability" has led lower federal courts to decide at the preliminary injunction stage the merits of cases arising out of labor disputes. ${ }^{12}$ The note deinonstrates that a presumption of arbitrability would allow the courts to focus on traditional equitable standards for injunctive relief, such as the nature of the harm threatened, so that they can determine whether an injunction is warranted, despite the NorrisLaGuardia ban, without reaching the merits of the underlying dispute. ${ }^{13}$ The note examines the manner in which the shift in emphasis from equitable standards for injunctive relief toward a determination of arbitrability leads the federal courts into examination of the merits of the underlying dispute. ${ }^{14}$ This note proposes a return to the presumption of arbitrability in those cases im which the risk of usurping the arbitrator's role is greatest, those in which the conduct sought to be enjoined is the same conduct allegedly in violation of the collective bargaining agreement. ${ }^{15}$ This solution would protect the arbitrator's role as interpreter of the collective bargaining agreement by minimizing the level of permissible judicial involvenent in the merits of the dispute.

\section{HISTORY AND BACKGROUND}

\section{A. Development of a National Labor Policy.}

Judicial involvement in labor disputes was the accepted norm at common law. Prior to 1932, employers could readily obtain mjunctive relief against striking employees by resort to sympathetic courts. ${ }^{16}$ Injunctious would issue whenever a complainant invoked the due process clause of the fifth and fourteenth amendments to protect his property. ${ }^{17}$ The courts often held that employers possessed property rights in the

11. See generally Buffalo Forge Co. v. United Steclworkers, 428 U.S. 397 (1976) (concentrating on arbitrability).

12. See infra Section II.

13. See infra notes $93-127$ and accompanying text.

14. See infra notes $59-64$ and accompanying text.

15. See infro notes 106-32 and accompanying text.

16. See Boys Markets, Inc. v. Retail Clerks Union, Local 770, 398 U.S. 235, 251 (1970); see also Shank, supra note 4, at 899.

17. Cf. Limiting Scope of Injunctions in Labor Disputes, Hearings on S. 1482 Before the Subcomm of the Senate Comm on the Judiciary, pt. 4, 70ih Cong., 1st Sess. 681, 698 (1928) (statement of Wimter S. Martin, atty. for Am. Fed. of Labor) [hereinafter cited as Martin, Statement to Subcomm] ("The only vague and intangible rights that are now protected by injunction are these labor rights .... In labor cases it is issued because the right to the earnings from labor is considered as a property right which should be protected at any cost by injunction."); id. at 703 . 30 (further explaining use of injunctions to protect property interests in labor). 
uninterrupted employment of their labor force.18 This notion of a property interest in a human being or his services should have been discarded shortly after the adoption of the thirteenth amendment. ${ }^{19}$ Congressmen who worked on labor legislation during the Depression voted to ban the granting of injunctions in labor disputes because they believed that use of an injunction to compel men to remain at work created a condition of involuntary servitude. ${ }^{20}$

The passage of the Norris-LaGuardia Act in 1932 reflected the congressional concern that a pro-inanageinent judiciary was aiding employers by failing to protect the thirteenth amendment rights of employees.21 Section 4 of the Act prohibited federal courts froun granting injunctive rehef in any suit arising out of a labor dispute. 22 In practice, the Act did not entirely prevent employers from obtaining injunctions, which were still available in many state courts. ${ }^{23}$ Nevertheless, strikes flourished as a result of the Norris-LaGuardia prohibition, and the labor movement grew in strength.

The National Labor Relations Act of 1935, commonly referred to as the Wagner Act, ${ }^{24}$ further tipped the balance in favor of the unions. ${ }^{25}$ The stated purpose of the Wagner Act was to curb various management activities that tended to discourage employee participation in collective action. ${ }^{26}$

18. The Supreme Court, in Bailey v. Alabama, 219 U.S. 219 (1911), attempted to halt the practice of treating an individual's labor as his employer's property. Justice Hughes, writing for the majority, declared that: "The plain intention [of the thirteenth amendment] was to abolish slavery of whatever name and form . . . ; to make labor free, by prohibiting that control by which the personal service of one man is disposed of or coerced for another's benefit which is the essence of involuntary servitude." Id. at 241; see also Martin, Statement to Subcomm, supra note 17, at 717-20 (discussing Bailey).

19. See Martin, Statement to Subcomm, supra note 17, at 696, 720-22.

20. See id. at 721 .

21. Gould, On Labor Injunctions Pending Arbitration: Recasting Buffalo Forge, 30 STAN. L. REV. 533, 534-35 (1976) ("The Norris-LaGuardia Act of 1932 embodied a congressional reaction against the federal judiciary's partiality" toward employers.); see also 75 CoNG. REC. 4915-18 (1932) (statement of Sen. Wagner).

22. For the pertinent text of the Norris-LaGuardia Act, see supra note 1.

23. In Avco Corp. v. Aero Lodge No. 735, 390 U.S. 557 (1968), the Supreme Court ameliorated the effect of Charles Dowd Box Co. v. Courtney, 368 U.S. 502, 502-06 (1962), which held that Taft-Hartley does not divest state courts of jurisdiction over suits for violation of contracts between employers and labor organizations, without resolving whether parties could circumvent the anti-injunction provision of Norris-LaGuardia by seeking redress in state courts. See 390 U.S. at 560 n.2. The Avco Court provided for the removal of section 301(a) [Taft-Hartley injunction] actions initially brought in state court to federal court under the federal question reinoval jurisdiction of 28 U.S.C. $\$ 1441$ (1976). See Avco, 390 U.S. at 560 n.2.

24. 49 Stat. 449 (1935) (codified as amended at 29 U.S.C. $\$ \$ 151-166$ (1976)).

25. Boys Markets, Inc. v. Retail Clerks Union, Local 770, 398 U.S. 235, 251 (1970).

26. See 29 U.S.C. $\$ 151$ (1976). In his statement before the Senate Committee on Education and Labor, Senator Wagner noted that since the passage of the National Industrial Recovery Act, 
The labor movement gained momentum in the twelve years that followed the adoption of the Wagner Act. By 1947, Congress became concerned that unions were gaining strength disproportionately and perceived a need to protect both employers and employees from unfair labor tactics by unions. Congress passed the Labor-Management Relations Act of 1947, commonly known as the Taft-Hartley Act, to equalize bargaining strength and further encourage unions and employers to enter into collective bargaining agreements. ${ }^{27}$ The Act provided the judiciary with a renewed role in the settlement of labor disputes. ${ }^{28}$ Under section 301 of the Act, if a union and an employer are parties to a collective bargaining agreement, ${ }^{29}$ a suit to enforce that agreement can properly be entertained in federal court.

Simce the passage of the Taft-Hartley Act, federal courts have tried to accommodate two conflicting policies. ${ }^{30}$ The Norris-LaGuardia Act instructed the courts not to involve theinselves in the labor dispute settlement process. ${ }^{31}$ The Taft-Hartley Act, on the other hand, permitted federal courts to settle disputes concerning violation of the very agreement embodying the dispute settling mechanism. ${ }^{32}$ The labor policies of these Acts conflict because Congress apparently neglected to revise

development of collective action had been "so one sided that there is danger of a worse balance than persisted in the past." To Create a National Labor Board: Hearings on S. 2926 Before the Senate Comm on Education and Labor, 73d Cong, 2d Sess. 8 (1934) (statement of Sen. Wagner). In addition he claimed that trade associations were being strengthened while labor organizational efforts were being thwarted. Id.

27. See Taft-Hartley Act $\& 201,61$ Stat. 152 (1947) (codified at 29 U.S.C. 8171 (1976)).

28. For the text of $\& 301(\mathrm{a})$, see supra note 6 .

29. Justice Douglas defined a collective bargaining agreement as "an effort to erect a system of industrial self-government." United Stcelworkers v. Warrior \& Gulf Navigation Co., 363 U.S. 574,580 (1960).

30. It has been argued that section 301 [Taft-Hartley] enforcement should override NorrisLaGuardia because injunctions enforcing contract obligations were not a central concern of Norris-LaGuardia. Cantor, Buffalo Forge and Injunctions Against Employer Breaches of Collective Bargaining Agreements, 1980 Wis. L. REv. 247, 251. See generally Boys Markets, Inc. v. Retail Clerks Union, Local 770, 398 U.S. 235, 249-53 (1970). The argument for injunctive relief in furtherance of contract obligations received support in judicial discussions of the Railway Labor Act, 44 Stat. 577 (1926) (codified at 45 U.S.C. 8152 (1976)), although the Railway Labor Act obligations are statutory rather than contractual. See, e.g., Chicago \& N.W. Ry. v. United Transp. Union, 402 U.S. 570, 583 (1971). See generally Cantor, supra.

31. See supra note 1.

32. Accord Textile Workers Union v. Lincoln Mills, 353 U.S. 448, 450-51 (1957) (section 301 "authorizes federal courts to fashion a body of federal law for the enforceinent of these collective bargaining agreements and includes within that federal law specific performance of promises to arbitrate grievances under collective bargaining agreements"). The Court based its interpretation of section 301 on the philosoplyy of the section as enunciated in the Senate Report: "Statutory recognition of the collective agreement as a valid, binding and enforceable contract is a logical and necessary step. It will promote a higher degree of responsibility upon the parties to such agreements, and will thereby promote industrial peace." Id. at 454 (quoting S. REP. No. 105, 80th Cong., 1st Sess. 17 (1947)). 
the provisions of the Norris-LaGuardia Act to make them consistent with the change in congressional concerns between 1932 and 1947.33 The task of accommodation, therefore, fell on the courts by default.

\section{B. The Impact of Reconciling Norris-LaGuardia with Taft-Hartley on} the Judiciary's Approach to Requests for Injunctions in Labor Disputes.

The Supreme Court took advantage of its earliest opportunity to interpret the authorization contained in section 301 of the Taft-Hartley Act. In Textile Workers Union v. Lincoln Mills, ${ }^{34}$ decided in 1957, the Court held that the Taft-Hartley Act enabled federal courts to "fashion a body of federal law for the enforcement of . . . collective bargaining agreeinents . . . includ[ing] within that federal law specific performance of promises to arbitrate grievances under collective bargaining agreements." 35 The Lincoln Mills Court based its holding on the primciples that the employer's agreement to arbitrate was the quid pro quo for the union's agreement not to strike and that the procedural requirements of section 7 of Norris-LaGuardia would not be applied to frustrate a federal court's power to enforce an employer's obligation to arbitrate under section 301 of Taft-Hartley. ${ }^{36}$ Norris-LaGuardia did not deprive the courts of power to issue injunctions to compel arbitration, because such compulsion was not "part and parcel of the abuses against which the Act was aimed." ${ }^{37}$ According to the Lincoln Mills Court, because Congress favored settleinent of disputes by arbitration, the courts were free from the restrictions of Norris-LaGuardia if the action to compel arbitration was brought under section 301 of the TaftHartley Act.

Three years after Lincoln Mills, the Supreme Court handed down decisions in three successive cases involving the United Steelworkers of America. In what has commonly been referred to as the "Steelworkers Trilogy,"38 the Court sought to preclude judicial determination of the

33. See Boys Markets, Inc. v. Retail Clerks Union, Local 770, 398 U.S. 235, 251 (1970).

34. 353 U.S. 448 (1957).

35. Id at 451. The relief in section 301 cases "varies-from specific performance of the promise to arbitrate. . . to enforcement or annulment of an arbitration award . . . to an award of compensatory damages . . , and the like." Avco Corp. v. Aero Lodge No. 735, 390 U.S. 557, 561 (1968) (citations omitted).

36. 353 U.S. 448, 455, 458-59 (1957). The Court stated that "section 8 of the Norris-LaGuardia Act does, indeed, indicate a congressional policy toward settlenent of labor disputes by arbitration, for it demies imjunctive relief to any person who has failed to make 'every reasonable effort' to settle the dispute by . . . voluntary arbitration.' "Id at 458.

37. Id at 458.

38. United Steelworkers v. American Mfg. Co., 363 U.S. 564 (1960) (dispute over employer's refusal to arbitrate grievance filed by employee who was disabled on the job); United Steelworkers 
merits of labor disputes by emphasizing equitable standards for injunctive relief rather than contractual considerations. The Court interpreted the Wagner Act's provisions encouraging arbitration of labor disputes to mean that federal courts should not delve into the substantive provisions of the disputed labor contract; instead, the courts sliould confine themselves to coinpelling arbitration when there is an arbitration clause included in the contract. ${ }^{39}$ The Court held that federal courts should resolve all doubts regarding arbitrability by presuming that the dispute is covered by the arbitration clause and should treat all arbitration awards as presumptively valid. ${ }^{40}$ The Court thus attempted to confine the adjudicative function to "ascertaining whether the party seeking arbitration is inaking a claim which on its face is governed by the contract," and admonished the courts that they have "no business weighing the merits of the grievance."4l Despite its intentions to the contrary, the Steelworkers Trilogy Court actually laid the groundwork for judicial forays into the merits when it required that a dispute be arbitrable, albeit presuinptively, before the trial court could determine whether an injunction to compel specific performance of the contract was warranted under ordinary equitable standards for injunctive relief.

The Supreme Court subsequently held in Sinclair Refining Co. v. Atkinson ${ }^{42}$ that the Taft-Hartley Act did not mitigate the impact of the Norris-LaGuardia Act's ban on injunctions. The Court made no attempt to reconcile the Sinclair decision witl its prior lioldings in Lincoln Mills and the Steelworkers Trilogy. The Sinclair decision effectively permitted unions to enter into collective bargaming agreements containing no-strike provisions and later to strike in defiance of such agreements without fear of judicial intervention. The Court's decision in Sinclair plainly ignored Taft-Hartley's grant of jurisdiction and deprived employers of incentive to enter into collective bargaiming

v. Warrior \& Gulf Navigation Co., 363 U.S. 574 (1960) (dispute over employer's refusal to arbitrate grievance regarding contracting out); United Steelworkers v. Enterprise Wheel \& Car Corp., 363 U.S. 593 (1960) (dispute over provision for reinstatement with backpay subsequent to an arbitrator's finding in favor of the union member).

39. See United Steelworkers v. American Mfg. Co., 363 U.S. 564, 567-69 (1960); United Steelworkers v. Warrior \& Gulf Navigation Co., 363 U.S. 574, 582-83 (1960); United Steclworkers v. Enterprise Whcel \& Car Corp., 363 U.S. 593, 596 (1960).

40. See United Steelworkers v. Warrior \& Gulf Navigation Co., 363 U.S. 574, 585 (1960).

41. United Steelworkers v. American Mfg. Co., 363 U.S. 564, 568 (1960).

42. 370 U.S. 195, 213 (1962), overruled, Boys Markets, Inc. v. Retail Clerks Union, Local 770, 398 U.S. 235 (1970). 
agreements. ${ }^{43}$ Scholarly criticism ${ }^{44}$ and lower court efforts ${ }^{45}$ to undermine the Sinclair holding culminated in the overruling of Sinclair in Boys Markets, Inc. v. Retail Clerks Union, Local 770.46

In Boys Markets, the Supreme Court created an exception to the Norris-LaGuardia Act's prohibition against the granting of injunctive relief. The Court upheld an mjunction against a strike that had been called in violation of a no-strike clause in the parties' collective bargaining agreement.47 The Boys Markets Court held that the use of injunctive relief to further the policy behind the Wagner Act favoring the peaceful resolution of labor disputes was not contrary to the policy behind the Norris-LaGuardia Act. ${ }^{48}$ Hence, injunctions against strikes pending arbitration were excepted from the general Norris-LaGuardia ban whenever the collective bargaining agreement contained a nostrike clause. ${ }^{49}$

43. See Sinclair, 370 U.S. at 216 (Brennan, J., dissenting) ("Our duty . . . is to seek out that accommodation of [Norris-LaGuardia and Taft-Hartley] which will give the fullest possible effect to the purposes of both.").

44. See generally Aaron, Strikes in Breach of Collective Bargaining Agreements: Some Unanswered Questions, 63 CoLum. L. Rev. 1027 (1963); Dunau, Three Problems in Labor Arbitration, 55 VA. L. Rev. 427 (1969); Keene, The Supreme Court, Section 301 and No-Strike Clauses: From Lincoln Mills to Avco and Beyond, 15 VILL. L. REv. 32 (1969); Kieman, Availability of Injunctions Against Breaches of No-Strike Agreements in Labor Contracts, 32 ALB. L. REv. 303 (1968); Wellington, The No-Strike Clause and the Labor Injunction: Time for a Re-examination, 30 U. PTrT. L. REV. 293 (1968); Wellington \& Albert, Statutory Interpretation and the Political Process: A Comment on Sinclair $v$. Atkinson, 72 Y ALE LJ. 1547 (1963).

45. The courts of appeals also tried to undermine Sinclair. See, e.g., New Orleans S.S. Ass'n v. General Longshore Workers, 389 F.2d 369, 371-72 (5th Cir.) (Sinclair does not prevent federal district courts from enforcing an arbitrator's order to terminate work stoppages even though this amounts, in effect, to an injnnction), cert. denied, 393 U.S. 828 (1968).

46. 398 U.S. $235,240-55$ (1970).

47. In Boys Markets, the dispute arose when employees who were not members of the union rearranged the frozen food cases in one of the coinpany's supermarkets. When the employer would not accede to the union's demand that the cases be restocked by union members, the union called a strike. The district court enjoined the strike; the United States Court of Appeals for the Ninth Circuit reversed under Sinclair. See Boys Markets, Inc. v. Retail Clerk's Union, Local 770, 416 F.2d 368, 370 (9th Cir. 1969). The Suprene Court reversed the Nimth Circuit and overruled Sinclair. See Boys Markets, 398 U.S. at 238.

48. The Court stated that the "central purpose of the Norris-LaGuardia Act to foster the growth and viability of labor organizations is hardly retarded-if anything, this goal is advanced-by a remedial device that merely enforces the obhigation that the umion freely undertook under a specifically enforceable agreenent to submit disputes to arbitration." 398 U.S. 235, 25253 (1970).

49. Injunctions against strikes are permitted when the strike is both in breach of a no-strike obligation and over an arbitrable grievance that the parties are contractually bound to arbitrate. Sea-Land Serv., Inc. v. International Longshoremen's Ass'n., 625 F.2d 38, 41 (5th Cir. 1980). Justice Brennan narrowed the holding in Boys Markets to cover only situations in which the collective bargaining agreement contained arbitration as a mandatory grievance procedure. Boys Markets, 398 U.S. at 253. 
The Boys Markets Court sought to protect the role of the arbitrator by requiring that employers be ordered to arbitrate as a condition for the granting of imjunctive rehef. 50 The purpose of this requirement is to force a reluctant party to the bargaining table, rather than the court merely enjoining the self-help to which it had resorted. ${ }^{51}$ This requirement also ensures that the party seeking imjunctive rehef has first exhausted all other reasonable methods of resolution.

In order for the Boys Markets exception to the congressional ban on imjunctive relief to apply, the collective bargaining agreement in question must contain a "mandatory grievance adjustinent or arbitration procedure."52 In addition, the Court in Boys Markets held that courts should consider the following equitable standards for injunctive relief: whether it appears a breach has occurred or will be committed; whether such a breach will result in irreparable larm; and whether the complaining party will be mjured more by the refusal to issue the imjunction than the defending party will be injured by its issuance. ${ }^{53}$

In 1976, the Supreme Court placed an additional limitation on a party's ability to gain mjunctive relief in a labor dispute. In Buffalo

50. See Boys Markets, 398 U.S. at 254; see also Emery Air Freight Corp. v. Local 295, Int'1 Bhd. of Teamsters, 449 F.2d 586, 588-89 (2d Cir.) (expanding Boys Markets by requiring that both parties be contractually bound to arbitrate), cert. denied, 405 U.S. 1066 (1971). See generally Shank, supra note 4 (describing the employer's duty to arbitrate as a condition to the granting of injunctive rehef).

51. See Boys Markets, 398 U.S. at 248-49, 252. In the Boys Markets opinion, the Court "determined that the dissenting opinion in Sinclair states the correct principles concerning the accommodation necessary between the seemingly absolute terms of the Norris-LaGuardia Act and the poticy considerations underlying \& 301(a)." 398 U.S. at 249. The dissenting opinion in Sinclair suggested:

A District Court entertaining an action under $\$ 301$ may not grant injunctive relief against concerted activity unless and until it decides that the case is oue in which an injunction would be appropriate despite the Norris-LaGuardia Act. When a strike is sought to be enjoined because it is over a grievance which both parties are contractually bound to arbitrate, the District Court may issue no injunctive order until it first holds that the contract does have that effect; and the employer should be ordered to arbitrate, as a condition of his obtaining an injunction against the strike. Beyond this, the District Court must, of course, consider whether issuance of an injunction would be warranted under ordinary principles of equity-whether breaches are occurring and will continue, or have been threatened and will be committed; whether they have caused or will cause irreparable injury to the employer, and whether the einployer will suffer more from the denial of an mjunction than will the union from its issuance.

Sinclair, 370 U.S. at 228 (Brennan, J., dissenting), quoted in Boys Markets, 398 U.S. at 254.

52. Boys Markets, 398 U.S. at 253.

53. See id. at 254 (quoting Sinclair, 370 U.S. at 228 (Brennan, J., dissenting)).

The reference to "property" was dropped by the Court from what otherwise appears to be a paraphrasing of the language found in section 7 of the Norris-LaGuardia Act. See 47 Stat. 71 (1932) (codified at 29 U.S.C. $\& 107$ (1976)). One possible explanation for this omission is the Court's deference to the states on matters-such as the protection of property-that are more properly within the states' police power. Protection of free speech and free labor, on the other hand, are first and thirteenth amendinent considerations, respectively, and are more properly handled by the judiciary. 
Forge Co. v. United Steelworkers, ${ }^{54}$ the Court refused to issue an injunction against a sympathy strike because the strike was not over a dispute covered by the arbitration provisions of the collective bargaining agreeinent. ${ }^{55}$ Hence, the Boys Markets exception to Norris-LaGuardia's ban on injunctive relief, contingent as it was on the issuance of a concurrent order to compel arbitration, did not apply. The Court noted that a sympathy strike, by its very nature, is not a grievance over which the union and the employer could reach an agreement through arbitration; in a sympathy strike, the terms and conditions of employment being challenged are those of a sister union and not those of the striking union. ${ }^{56}$ The holding of Buffalo Forge was that the Boys Markets exception to Norris-LaGuardia's ban on injunctive relief ${ }^{57}$ applied only when the alleged breach of the collective bargaining agreement frustrated a pledge to arbitrate..$^{58}$ The Supreme Court thus narrowed its broad exception to Norris-LaGuardia to circumstances in which the underlying grievance, not simply the activity sought to be enjoined, was covered by a mandatory arbitration clause contained in the collective bargaining agreement governing the parties. In so holding, the Court moved one step further in the direction of concentrating on the arbitrability issue instead of the equitable standards for injunctive relief.

The Buffalo Forge decision represented a shift in the Court's emphasis from the nature of the injury threatened to the content of the labor agreement. 59 Recognizing this shift, Justice Stevens dissented from the Court's opinion, ${ }^{60}$ arguing that sympathy strikes did not implicate the central concern of Norris-LaGuardia. ${ }^{61}$

54. 428 U.S. 397 (1976).

55. See id. at $411-13$.

56. Id. at 407. Sympathy strikes are not arbitrable grievances because the workers are not striking over a breach by their employer of their collective bargaining agreement; rather, they are striking because the employer of workers with whom they sympathize is violating an agreement to which they are not parties.

57. Boys Markets does not contain the only exception to the Norris-LaGuardia Act. In United States v. United Mine Workers, 330 U.S. 258 (1947), the Supreme Court held that NorrisLaGuardia does not apply to the United States as an employer.

58. 428 U.S. at 409-12. In Buffalo Forge, the Court would have allowed an imjunction preserving the status quo pending arbitration only when such an imjunction would be "essential to carry out promises to arbitrate and to implement the private arrangements for the administration of the contract." Id. at 411. The phrase "frustrate the arbitral process" was interpreted in Lever Bros. v. International Chem. Workers Union, Local 217, 554 F.2d 115 (4th Cir. 1976), to nean conduct taken by a party that.would render the arbitrator's award no more than a hollow formality because, when ordered, the award would not return the parties substantially to the status quo ante. Id. at 123.

59. Shank, supra note 4, at 917.

60. 428 U.S. at 415 (Stevens, J., dissenting). Justice Stevens was joimed by three other Justices-most notably Justice Brennan, who wrote a concurrence in the Steelworkers Trilogy, the dissent in Sinclair. and the majority opimion in Boys Markets.

61. Id. at $428-32$ (Stevens, J., dissenting). Justice Stevens based his opimion not only on the 


\section{Judiclal Determination of ARbitrability as a Means of REACHING THE MERITS OF LABOR DisPUTES}

The problems created by focusing on the arbitrability of the grievance underlying the conduct sought to be enjoined becoine most apparent when a union is seeking an imjunction against an employer's actions. Under these circumstances, the conduct that the union seeks to enjoin may be identical to the conduct that precipitated the underlying dispute or that it claims to be in violation of the collective bargaining agreement. ${ }^{62}$ Hence, making the determination of arbitrability the threshold issue necessarily mcreases the risk that the case will be disposed of on its merits at the preliminary mjunction stage. ${ }^{63} \mathrm{~A}$ recent case decided by the United States Court of Appeals for the Sixth Circuit illustrates the consequences of focusing on arbitrability, rather than potential injury, as the threshold issue im preliminary injunction hearings. ${ }^{64}$

United Auto Workers v. Dana Corp. raises a number of important issues. At the threshold, there is the issue of whether the Norris-LaGuardia Act, and the Supreme Court cases construing it, apply when a union is seeking an imjunction against an einployer. The Dana case also raises the more fundanental issue of whether the congressional policy favoring resolution of labor disputes through arbitration is consistent with the Dana court's extensive examination of the merits. The question then arises how best to further that policy and protect the role of the arbitrator. Even the Dana decision suggests that traditional equitable standards provide sufficient bases for disposing of requests for imjunctive relief without necessitating an examination of the merits of the underlying dispute. Thus the final question raised by Dana is by what mechanisun the courts can turn their attention to equitable standards for ijunctive relief, yet preserve the arbitrator's role in deciding the

presumptions outlined in the Steelworkers Trilogy, see supra text accompanying note 40, but also on the Supreme Court's decision in Gateway Coal Co. v. United Mine Workers, 414 U.S. 368 (1974). In Gateway Coal, the Court held that a promise not to strike should be implied unless there is an express provision in the contract to the contrary. See id. at 381. The Court previously had held that courts should not imply a promise not to strike as the quid pro quo for a promise to arbitrate. See Textile Workers Union v. Lincoln Milis, 353 U.S. 448, 455 (1957).

62. In the case of strikes by unions in violation of no-strike agreements, the employer is seeking an injunction against the strike, but the grievance is typically over wages, hours, or working conditions. In the case of activities by employers in violation of collective bargaining agreements, the union is seeking an injunction against the very activity giving rise to the grievance.

63. See Cantor, supra note 30, at 265.

64. See UAW v. Dana Corp., 679 F.2d 634 (6th Cir. 1982), reh'g en banc granted and opinton vacated, id at 654 (Aug. 12, 1982). 
merits of a dispute, if the courts must make any grant of such relief contingent upon a finding that the underlying dispute is arbitrable. This section examines each of these issues and suggests a possible solution.

\section{A. United Auto Workers v. Dana Corp.}

A summary of the facts of United Auto Workers $v$. Dana Corp. will provide a basis for discussion of the problems inherent in the determination of arbitrability. A collective bargaining agreement between Dana, a multistate corporation, and the United Auto Workers (UAW) provided that disputes "of any kind" arising between the company and the union should be processed through a detailed grievance procedure. ${ }^{65}$ The agreement provided that if a dispute over "interpretation and/or application of terms" could not be resolved by designated representatives of each side, the dispute was to be submitted to an arbitrator whose determination was to be "final and binding upon both the Union and the company." 66 In a letter intended to supplement this agreement, Dana promised to maintain a neutral position whenever the UAW became involved in organizing Dana employees. ${ }^{67}$

The dispute giving rise to the litigation began when the UAW attempted to organize employees at the Wix Corporation, a wholly owned subsidiary of Dana. ${ }^{68}$ When the president of Wix distributed a letter addressed to the Wix employees stating that Dana was opposed to unionization of the plants, the UAW filed a grievance according to the procedure set forth in the collective bargaming agreement, complaming that the Wix Corporation's president had violated Dana's neutrality promise. 69 When the parties were unable to resolve the grievance, the UAW appealed directly to the Permanent Arbitrator. ${ }^{70}$ When Dana failed to respond to the UAW's request for emergency ar-

65. Id at 636. This procedure was to serve as the exclusive dispute settling mechanism.

66. Id

67. Id at 637.

68. Id. The UAW notified Dana by letter of its organizational efforts and reminded Dana of the neutrality agreement. Upon the UAW's petition to the National Labor Relations Board (NLRB), an election to determine a collective bargaining agent for the Wix employees was set for June 12, 1980.

69. Id. at 638.

70. Id. Dana cancelled the arbitration date because it was unprepared. Subsequently, both parties agreed to postpone the hearing indefinitely upon Dana's express promise to refrain from committing the challenged acts. Once again, however, the UAW sought arbitration, complaining that violation of the agreement persisted. 


\section{bitration, the Union filed a request in federal district court ${ }^{71}$ for a tem-}

71. As an alternative to court action, the UAW could have pursued an unfair labor practice charge against Dana before the NLRB. Section 10(j) of the National Labor Relations Act (NLRA), as amended, allows the NLRB discretion to petition for injunctive relief whenever it believes such relief is warranted. See 29 U.S.C. 8 160(j) (1976). The NLRB will generally exercise this discretion only if failure to maintain the status quo would render any subsequent Board determination meaningless. Although the UAW probably could have obtained a 8 10j) injunction, it chose not to proceed through the NLRB. The UAW probably believed that an NLRB decision, even one as preliminary as this, would take too long to provide rehef prior to the election. Even if it were under less of a time constraint, the UAW would likely liave proceeded through the NLRB only if it had perceived the Board as a more "favored" plaintiff than itself. There is no evidence that this was the case.

The authorization contained in sections $10(j)$ and $10(l), 29$ U.S.C. $\& 160(j),(l)(1976)$, carves out an exception to the Norris-LaGuardia ban on the issuance of injunctions in labor disputes. The imterplay between the NLRA, Norris-LaGuardia, and Taf-Hartley raises a number of questions. First, if an action constitutes both a violation of a collective bargaining agreement and an unfair labor practice, what body hes jurisdiction? $S e e, e . g$. William E. Arnold Co. v. Carpenters Dist. Council, 417 U.S. 12 (1974) (NLRB does not have exclusive jurisdiction when an activity is both an unfair labor practice and a breach of a collective bargaining agreenent). Second, is exhaustion of administrative remedies required under these circumstances? Section 8 of NorrisLaGuardia provides that a complainant may not get injunctive relief if he fails to inake "every reasonable cffort to settle such dispute either by negotiation or with the aid of any available governmental machinery." 29 U.S.C. 8108 (1976) (emphasis added). This would seem to suggest that there is an exhaustion requirement. On the other hand, the legislative history of the NLRA reveals Congress" imtent that "[o]nce parties have made a collective bargaining contract the en. forcement of that contract should be left to the usual processes of the law and not to the National Labor Relatións Bóard." CoMmITTEE OF CONFERENCE, REPORT ON THE LABOR-MANAGEMENT Relations ACT of 1947, H.R. ReP. No. 510, 80th Cong., lst Sess. 42 (1947), reprinted in 1947 U.S. CODE CONG. SERv. 1147. Bur cf. McLeod ex rel. NLRB v. American Fed'n of Television \& Radio Artists, N.Y. Local, 234 F. Supp. 832, 840 (S.D.N.Y.) ("when the Board petitions to enjoin an unfair labor practice the mere fact that this unfair labor practice involves a clause [of a collective bargaining agreement] subject to arbitration should not reinove this case from the broader rules of law applicable to [suits by the Board for temporary injunctive relief pending determination of the unfair labor practice charges] and place it totally within the realm of section 301(a) suits which govern suits by employer and/or employee") (emphasis in original), affd, 351 F.2d 310 (2d Cir. 1964). Third, can an arbitrator decide issues that come under the unfair labor practice provisions of the NLRA? Section 10 of the NLRA gives the NLRB exclusive jurisdiction in such cases, but the NLRB can defer to an arbitrator. See 29 U.S.C. 8 160(a), (k) (1976). For discussion on this point, see Spielberg Mfg. Co., 112 N.L.R.B. 1080 (1955) (the "Spielberg Doctrine" provides that the NLRB will not defer $t 0$ an arbitrator unless it is convinced that the arbitrator has fully and fairly considered the unfair labor practice issues); see also Note, Discriminatory Discipline of Union Representatives for Breach of their "Higher Duty" in Illegal Strikes, 1982 DUKE L.J, 900, 928 n.158.

The interplay among the three statutes appears to produce the following pattern of effects: (1) Taft-Hartley applies to non-arbitrable contract disputes; (2) the NLRA's unfair labor practice provisions apply to non-"contracted away" unfair labor practice disputes; and (3) Norris-LaGuardia applies when there is no contract or when the contract dispute is not arbitrable. When the contract dispute may be arbitrable, however, and one party refuses to arbitrate even the threshold issue of whether the contract dispute is subject to arbitration, Norris-LaGuardia does not apply, and the court may issue an injunction pending determination by the arbitrator of the coverage issue under the court's Taft-Hartley powers. If the dispute is covered by the arbitration clause, the arbitrator hes jurisdiction; if it is not covered by the arbitration clause, the federal court has jurisdiction. 
porary restraining order, pending arbitration, enjoining Dana from further action allegedly in violation of the agreenent. ${ }^{72}$

The district court did not limit itself to the issue of whether the alleged violation of the neutrality agreement was an arbitrable dispute; ${ }^{73}$ instead, it proceeded to determine, based on the specific language of the agreement, that the employer's statements violated the neutrality agreeinent. ${ }^{74}$ The district court dispensed with the NorrisLaGuardia Act's ban on injunctive relief, under the authority of Boys Markets, and turned to traditional equitable standards to assess the propriety of injunctive relief. The court found that the union "would suffer irreparable harm if Dana were unrestrained" because arbitration subsequent to the election would be a "lollow formality," and entered an order restraining Dana from further departure from the terms of the agreement until the union's grievance could be arbitrated. ${ }^{75}$ Shortly thereafter, the UAW alleged that Dana was contimuing to breach its neutrality agreement despite the restraining order. ${ }^{76}$ The district court found Dana in contempt of court and granted the UAW injunctive rehief. 77

Dana argued on appeal that the Norris-LaGuardia Act barred the district court froin granting the injunction. ${ }^{78}$ In addition, the coinpany argued that, to the extent the injunction served as a proscription against future communication, it constituted an unconstitutional prior restramt

72. UAW v. Dana Corp., 679 F.2d 634, 638 (6th Cir. 1982), reh'g en banc granted and opinion vacated, id at 654 (Aug. 12, 1982). The district court opinion is reported at 104 L.R.R.M. (BNA) 2687 (N.D. Ohio 1980). The union filed its request for a temporary restraining order one week before the scheduled election.

73. The district court in Dana, "after hearing arguments of counsel for both parties, found that the dispute between the parties concerning defendant's activities at Gastonia was, . . . 'on its face, a breach of an agreement between plaintiff and defendant and [thus was] arbitrable under the terms of the applicable collective bargaining agreement." 679 F.2d at 638 (quoting 104 L.R.R.M. (BNA) at 2687-88).

74. $679 \mathrm{~F} .2 \mathrm{~d}$ at 638 . The existence of the neutrality agreement was critical to the court's finding that injunctive relief was warranted. In the absence of such an agreement, the injunction would have been barred by the express language of Norris-LaGuardia. Section 4 of the Act specifically states that no court of the United States may grant a temporary restraining order or an injunction to prohibit "[g]iving publicity to the existence of, or the facts involved in, any labor dispute, whether by advertising, speaking, patrolling, or by any other method not involving fraud or violence." 29 U.S.C. $8104(\mathrm{e})$ (1976).

75. 679 F.2d at $638-39$ (discussing proceedings at trial level) (paraphrasing 104 L.R.R.M. (BNA) at 2688).

76. 679 F.2d at 639 (discussing proceedings at trial level). Efforts by the union to compel arbitration proved fruitless. The day the election was to have taken place, the UAW withdrew its petition for election.

77. Id at $639-40$ (discussing proceedings at trial level). When the preliminary injunction was issued, Dana moved for a stay. Upon denial of its motion, Dana appealed to the Court of Appeals for the Sixth Circuit.

78. Id. at 640 . 
on free speech and press. ${ }^{79}$ The Court of Appeals for the Sixth Circuit based its affirmance of the district court's opinion on the union's demonstration that it had bcen irreparably harmed, statimg that an "arbitration award cannot restore a lost election." 80

\section{B. Application of the Norris-LaGuardia Act's Ban on Injunctive Relief in the Employer-Injunction Context.}

In Dana, ${ }^{81}$ the court of appeals faced the troublesome problem of applying the Boys Markets exception to Norris-LaGuardia's ban on injunctive relief, and the Buffalo Forge limitation on that exception, to a request for an imjunction against an employer, instead of to the more familiar case of a request $b y$ the employer. ${ }^{82}$ Noting that the problem presented by employer-imjunction cases had arisen in other circuits, ${ }^{83}$ the Dana court disposed of the issue by holding that "employer selfhelp measures which . .. undermine the arbitral process" are properly

79. Id -at 643. The constitutional question regarding prior restraint of free speech and press presented in Dana will not be discussed in this note. For a discussion of this question, see Kramer, Miller \& Bierman, Neutrality Agreements: The New Frontier in Labor Relations-Fair Play or Foul?, 23 B.C.L. REv. 39 (1981) (general discussion of prior restraint in the neutrality agreement context). See also Organization for a Better Austin v. Keefe, 402 U.S. 415, 419 (1971) ("Any prior restraint on expression comes to this Court with a 'heavy presumption' against its constitutional validity.") (citing Carroll v. President \& Comm'r of Princess Anne, 393 U.S. 175, 181 (1968)).

80. Dana, 679 F.2d at 643. Dana's petition for a rehearing en banc was granted by the Court of Appeals for the Sixth Circuit. In a decision without written opinion, the court vacated the panel decision. The trial cour, on remand, declared the case mooh because the parties had reached an agreement through arbitration. 679 F.2d 634 (6th Cir. 1982), reh'g en banc granted and opirion vacated, id at 654 (Aug. 12, 1982).

81. 679 F.2d 634 (6th Cir. 1982), reh'g en banc granted and opinion vacated, id at 654 (Aug. 12, 1982).

82. One commentator remarked that the Court in Buffalo Forge may well have decided the case "with one eye toward a spectre of employer injunction cases. Certainly, in a plethora of situations, readily available mjunctive relief would be attractive to unions. The fear of a flood of litigation unight be more substantial in this context than in sympathy strike cases." Cantor, supra note 30, at 268.

83. Lever Bros. v. International Chem. Workers Union, Local 217, 554 F.2d 115 (4th Cir. 1976), is the "reverse Boys Markets" case. The Lever Brothers court held that an "injunction to preserve the status quo pending arbitration may be issued either against a company or against a union ... . where it is necessary to prevent couduct by the party enjoimed from rendering the arbitral process a hollow formality." Id at 123. The Court of Appeals for the Third Circuit espoused a similar view in United Steelworkers v. Fort Pitt Steel Casting, 598 F.2d 1273 (3d Cir. 1979). It stated that "alihough the Supreme Court in Boys Markets enjomed a strike by a union, mjuzctions may in certain circumstances issue against acts taken or threatened by the employer." Id. at 1278. Boys Markets itself explicitly stated that from the time of Lincoln Mills it has been clear that "a union can obtain specific performance of an employer's promise to arbitrate grievances" without resistance from the Norris-LaGuardia Act. 398 U.S. 235, 242 (1970). 
the subjects of injunctive relief. ${ }^{84}$ Previously, Boys Markets had provided a ineans for employers to force unions to the arbitration table when a union had prematurely resorted to self-help by striking before seeking to arbitrate. The kind of imjunctive relief granted in Dana provides a similar inethod for unions to force an employer to arbitrate when the employer appears to be either resorting to self-help in heu of arbitration or simply violating the contract. 85 Both procedures encourage the goal of peaceful resolution of labor disputes, and should be applied with equal force. ${ }^{86}$

84. Dana, 679 F.2d at 642 (citing Lever Bros. v. International Chem. Workers Union, Local 217, 554 F.2d 115 (4th Cir. 1976)). Unions have previously sought to enjoin employers from conduct allegedly violative of collective bargaining agreenrents. See, e.g., United Steelworkers v. Fort Pitt Steel Casting, 598 F.2d 1273, 1278 (3d Cir. 1979); Burlesque Artists v. I. Hirst Enters., 267 F.2d 414 (3d Cir. 1959); Amalgamated Food Employees v. National Tea Co., 346 F. Supp. 875 (W.D. Pa), remanded, 474 F.2d 1338 (3d Cir. 1972); Local 90, Stone Mounters v. Welbilt Corp.. 178 F. Supp. 408, (E.D. Mich. 1959), affd, 283 F.2d 868 (6th Cir. 1960).

85. Dana could have been brought in the union-injunction context. If the UAW had struck after Dana failed to come to the bargaining table, it would have been justified in doing so because it had demonstrated its willingness to arbitrate. Under Norris-LaGuardia, Dana would then have been barred from obtaining imjunctive relief. If the purpose of a strike is to force a reluctant employer to arbitrate, the Boys Markets exception arguably should not apply. Boys Markets represented an effort to avoid situations in which an employer is powerless to stop a union strike instituted before the union has nuade an earnest effort to arbitrate. Boys Markets should offer no aid to Dana in such circumstances, despite the existence of an arbitrable grievance, because the policy reasons behind that decision are inapplicable. Granting an imjunction against the hypothetical strike would offend traditional equitable standards for injunctive relief. Dana, as the party refusing to arbitrate, would not come to the court with clean hands. Hence, if the court in Dana had not granted the UAW's request for an imjunction, Dana's hypothesized refusal would have been tantamount to encouraging a strike, a result in direct conflict with Congress' national labor policy of promoting peaceful resolution of labor disputes. See 29 U.S.C. $\$ \$ 141$ (b), 151 (1976). But see Boys Markets, Inc. v. Retail Clerks Umion, Local 770, 398 U.S. 235, 253-54 (1970) ("Nor does it follow from what we have said that imjunctive relief is appropriate as a matter of course in every case of a strike over an arbitrable grievance."); Shank, supra note 4, at 910 (citing Avco Corp. v. Local 787, UAW, 459 F.2d 968, 973 (3d Cir. 1972) ("Evidently, the issue of willingness to arbitrate nust be raised defensively to become part of the case.")).

86. Despite the logic inherent in equal application to both parties of imjunctions against concerted activity, the Court of Appeals for the Ninth Circuit recently decided not to grant an imjunction against an employer in Amalgamated Transit Umion, Div. 1384 v. Greyhound Limes, Inc., 550 F.2d 1237 (9th Cir.), cert. denied, 434 U.S. 837 (1977). Initially, the court granted injunctive relief to the union. The case then went to the Supreme Court, which remanded and instructed the Ninth Circuit to reconsider the case in hight of Buffalo Forge. See Greyhound Limes, Inc. v. Amalgamated Transit Union, Div. 1384, 429 U.S. 807 (1976). On remand, Judge Sneed, writing for the majority, based the reversal of his initial opinion on two grounds: (1) an employer's actions pending arbitration generally would not frustrate the arbitral process although a strike in the same situation would do so; and (2) the union would not suffer irreparable harm if its request for an imjunction were refused. 550 F.2d at 1238-39. Despite Judge Sneed's interpretation of the applicability of Buffalo Forge to employer-imjunction cases, his reasoning does not dictate the same result in Dana. Dana's actions pending arbitration did frustrate the arbitral process and did cause the UAW irreparable harm, because arbitration after the election could not restore the parties to their status quo ante. Furthermore, the Greyhound court reasoned that in the absence of an express or inplied promise on the part of the employer to maintain the status quo, an injunction to 
In United Steelworkers v. American Manufacturing Co., 87 the first case in the Steelworkers Trilogy, Justice Douglas, writing for the najority, introduced the quid pro quo analysis to labor dispute cases. Because the collective bargaining agreement in question contained no exception to the no-strike clause, the American Manufacturing Court refused to read such an exception into the grievance clause on the ground that one was the quid pro quo for the other. ${ }^{88}$ The Court scemed to recognize that, in labor negotiations, every agreeinent contains an exchange of promises. A union cannot extract a promise froin an employer without agreeing to something in return. Proper treatinent of einployer-injunction cases requires a recognition that there are two sides to this quid pro quo analysis. Employers must also make concomitant promises if they are to extract promises from unions. The Court's reasoning in Boys Markets that "einployers will be wary of assuming obligations to arbitrate specifically enforceable against them when no similarly efficacious remedy is available to enforce the concomitant undertaking of the union to refrain from striking," 89 is equally applicable when the positions are reversed. Unions, too, will be wary of agreeing to no-strike provisions unless they can obtain injunctions preventing employers from violating their contract obligations. 90

Despite the sound reasoning behind the quid pro quo analysis, an employer could argue, in respouse to a union's prayer for injunctive relief, that the Boys Markets exception to the statutory ban on mjunctive relief in labor disputes does not apply outside the strike context.91

preserve it pending arbitration could not be issued. 550 F.2d at 1239. See generally Comment, Injunctions Restraining Employers Pending Arbitration: Equity and Labor Policy, 82 Dick. L. Rev. 487, 503 (1978). Arguably, however, neutrality clauses on their face demonstrate a promise to maintain the status quo.

87. 363 U.S. 564, 564-69 (1960).

88. Id. at 567 ("There is no exception in the 'no strike' clause and none therefore should be read into the grievance clause, since one is the quid pro quo for the other.").

89. Boys Markets, Inc. v. Retail Clerks Union, Local 770, 398 U.S. 235, 252 (1970).

90. Id As section 4 of the Norris-LaGuardia Act, 29 U.S.C. \& 104 (1976), "principally insulates worker activity, and as injunctions against employers were not the kind of abuse against which Norris-LaGuardia was directed, there is a temptation to dismiss Buffalo Forge as largely irrelevant to employer injunctions." Cantor, supra note 30, at 263-64. Nevertheless, the Third Circuit has held that "if. . . the grievance procedures are indeed mandatory for the [union] . . . . we cannot say that the district court committed plain error in finding that those procedures are also mandatory for the Company." United Steelworkers v. Fort Pitt Steel Casting, S98 F.2d 1273, 1279 (3d Cir. 1979).

91. The employer-injunction context offers both sides an escape from the duty to arbitrate. A umion seeking an injunction against an employer would make the threshold argument that the Norris-LaGuardia injunction prohibition does not apply in the employer-injunction context. This argument is distinct froin the Boys Morkets rationale because it asserts a blanket exclusion from coverage rather than an exception to the Act. Moreover, the argument is not supported by the 
This argument, however, is untenable given the dictum in the Boys Markets opinion that refers to the reciprocal duties of employers and unions. ${ }^{92}$

\section{Preserving the Arbitrator's Role by Limiting Judicial Interpretation of Collective Bargaining Agreements.}

Whether an injunction is sought against an employer or against a union, the courts after Buffalo Forge have focused on the same question: is the grievance arbitrable? The Supreme Court has stated that "[n]o obligation to arbitrate a labor dispute arises solely by operation of law. The law compels a party to submit his grievance to arbitration only if he has contracted to do so."93 Presuniably, the parties can bargain collectively and yet not submit their disputes to an arbitrator, choosmg instead to use the courts. In such a case, the court's function under section 301(a) of the Taft-Hartley Act is expansive. ${ }^{94}$ But when, as in Dana, the parties have provided for arbitration as the sole method of dispute settlement, this choice impliedly limits the court's role either to compelling arbitration or to enforcing the arbitrator's award.95 Plainly, a court must sometimes issue a preliminary injunction to fuifill this role effectively. ${ }^{96}$

language of the Norris-LaGuardia Act. Not only is there no explicit provision excluding employer-injunction cases from its coverage, but there is indication of a contrary intent. 29 U.S.C. $\$ 113(b)$ (1976) defines "person participating or interested in a labor dispute" in terms that include both employers and unions.

92. See Boys Markets, 398 U.S. at 252-53.

93. Gateway Coal Co. v. Umited Mine Workers, 414 U.S. 368, 374 (1974).

94. Accommodation between Norris-LaGuardia and Taft-Hartley "allows the judge to apply the "usual processes of the law' but not to take the place of the arbitrator." Buffalo Forge Co. v. Umited Steelworkers, 428 U.S. 397, 431 (1976) (Stevens, J., dissenting). The "usual processes of the law" must necessarily entail detailed contract interpretation where the parties have. not provided for an arbitrator to serve this function. Where, however, an arbitration clause has been included, the "usual processes of the law" must necessarily be confined to considerations of equity. See id at 431-32.

95. The Boys Markets exception to Norris-LaGuardia's ban on injunctive relief is limited to the contours of 'the agreement between the parties. Within these limits, the district court may exercise its equitable powers. See Sea-Land Serv., Inc. v. International Longshoremen's Ass'n, 625 F.2d 38, 43 (5th Cir. 1980). As the Court in Buffalo Forge emphasized, "a district court should not use a Boys Markets injunction, intended to facilitate and encourage arbitration, to nsurp the very function of the arbitrator" by engaging in detailed contract interpretation. Waller Bros. Stone Co. v. United Stcelworkers, 620 F.2d 132, 137 (6th Cir. 1980). Nevertheless, in trying to narrow its holding by requiring an "arbitrable" dispute, the Supreme Court's Buffalo Forge opinion opened the way for decisions such as Dana, which require a federal district judge, in determining arbitrability, to look to the merits of the dispute before granting an injunction. Once authorized to look to the merits, district court judges are certain to find it difficult to stop short of actually deciding the merits of the case at the preliminary injunction stage.

96. A preliminary injunction has been described as "an extraordimary equitable tool of the courts wherein a party to the litigation-at the behest of his antagonist-is forbidden by the court 
In Dana, the district court engaged in a detailed examination of the employer's conduct that allegedly violated the neutrality clause, determining not only that the grievance was arbitrable, but also that the employer's conduct constituted a breach of the agreement.97 The district court im effect laid the collective bargaining agreement beside the letters and the text of the challenged speeches and determined that the speech was prohibited by the clause. Instead, the district court's function in Dana should have been limited to simply making a determination that the underlying issue might be arbitrable and preserving the status quo until the arbitrator could decide this issue. ${ }^{98}$ On the facts of Dana, such a determination could have been inade with little difficulty. All disputes involving "interpretation and/or apphcation of terms" were subject to the mandatory grievance procedure. 99 Examination of this provision and the provision covering the neutrality agreement would have been sufficient to enable the Dana court to base its issuance of the preliminary injunction upon a finding that the dispute might be arbitrable. ${ }^{100}$ The parties freely chose to have their grievances settled

to engage in designated conduct prior to any final determination . . . that such conduct ought to be proscribed." Metzger \& Friedlander, The Preliminary Injunction: Injury Without Remedy?, 29 Bus. LAw. 913, 913 (1974). There "is no power the exercise of which is more delicate, which requires greater caution, deliberation, and sound discretion, or [which is] more dangerous in a doubtful case" than the power to grant injunctive relief. W. BARRON \& A.J. HolTzOFF, FEDERAL Practice \& Procedure 1431 (C. Wright ed. 1958) (quoting Justice Baldwin in Bonaparte v. Camden \& A.R. Co., 3 F. Cas. 821,827 (C.C.N.J. 1830) (No. 1617)).

97. See UAW v. Dana Corp., 679 F.2d 634, 639 (6th Cir. 1982), reh'g en banc granted and opinion vacated, and id. at 654 (Aug. 12, 1982). The district court opinion is reported at 104 L.R.R.M. (BNA) 2687 (N.D. Ohio 1980). When the union reappeared in court complaining that Dana had violated the temporary restraining order, the district court went on to find that the "evidence left no room for any doubt whatsoever that the defendant had violated the terms." Dana, 679 F.2d at 639. It is difficult to imagine a more complete adjudication on the inerits than that demonstrated by the district court in Dana.

98. See Local 71, Int' 1 Bhd. of Teamsters v. Akers Motor Lines, Inc., 582 F.2d 1336, 1342 (4th Cir. 1978) ("Courts must avoid reaching the merits of arbitrable disputes; their function, within the narrow ambit of Boys Markets and Lever Brothers, is to make a determination that the underlying issues may be arbitrable, and preserve the status quo so that the arbitrators can first decide this preliminary issue, and then, if appropriate, decide the merits."), cert. denied, 440 U.S. 929 (1979). As the Court noted in Buffalo Forge,

the parties' agreement to adjust or to arbitrate their differences themselves would be eviscerated if the courts for all practical purposes were to try and decide contractual disputes at the preliminary mjunction stage. . . [ []] is difficult to believe that the arbitrator would not be heavily influenced or wholly pre-empted by judicial views of the facts and the meanings of contracts if this procedure is to be permitted.

428 U.S. at 412 (1976).

99. Dana, 679 F.2d at 636 . By limiting the court's function to presuming arbitrability, the question of the interpretation of the contract would be "properly left to the arbitrator, and not predetermined by the Court on the ruling on the preliminary injunction." Lever Bros. v. International Chem. Workers Union, Local 217, 554 F.2d 115, 119 (4th Cir. 1976).

100. This is the prevailing approach among the circuits. It minimizes the inquiry into the merits and allows the court granting ijjunctive rehef to rely upon traditional equitable standards 
by arbitration based on their confidence that the arbitrator's special expertise in the field would enable him to fill in the terms which the parties failed to adequately express in the contract.101 Arbitrators are chosen, in tieu of judges, to decide labor disputes precisely because they have such expertise. Arbitrators can consider such factors as "the effect upon productivity of a particular result, its consequence to the morale of the shop ... [ [and] whether tensions will be heightened or diminished," in addition to other factors that even the ablest judge cannot be expected to know because he cannot be as well informed in these areas. ${ }^{102}$ By examining the merits of the dispute, the district court usurped the arbitrator's function and denied the parties the benefit of their bargain. ${ }^{103}$

Arguably, the facts in Dana were somewhat unlike those conten1plated by the Supreme Court when it held in Buffalo Forge that an order compelling arbitration must be appropriate before injunctive relief can be awarded. Generally, expedited arbitration will minimize the harm that will occur if a temporary restraining order or preliminary injunction is improperly issued or denied. ${ }^{104}$ In the Dana situation, however, arbitration could not take place in time to save the election for the union. If the Dana decision is read as limiting judicial involvement at the pre-arbitration stage to situations in which arbitration would not have occurred in time to prevent the harmful activity against which the injunction was sought, then perhaps it is a defensible exten-

rather than a determination that a violation did in fact occur. Considerations of irreparable injury and the balance of harms are dispositive, "with only enough judicial inquiry into the merits to assume the presence of a substantial contractual claim. The advantage of this approach is that it diminishes judicial preemption of an arbitrator's role." Cantor, supra note 30, at 289-90. In Dana, there was some question whether the neutrality agreement was part of the collective bargaining agreement. Resolution of this issue would determine whether the mandatory grievance procedure applied. The arbitrator, however, should be allowed to decide this issue. The court need ouly determine that the neutrality clause may be part of the agreement to determine that the dispute may be arbitrable.

101. See United Steelworkers v. Warrior \& Gulf Navigation Co., 363 U.S. 574, 581-82 (1960).

102. Id. at 582. The parties rely on the arbitrator's "knowledge of the common law of the shop and their trust in his personal judgment to bring to bear considerations which are not expressed in the contract as criteria for judgment." Id. This position was reiterated in United Steelworkers v. Enterprise Wheel \& Car Corp.: "When an arbitrator is commissioned to interpret and apply the collective bargaining agreement, he is to bring his inforned judgment to bear in order to reach a fair solution of a problem." 363 U.S. 593,597 (1960).

103. See United Steelworkers v. Enterprise Wheel \& Car Corp., 363 U.S. 593, 598-99 (1960).

104. The underlying rationale of Buffalo Forge was that "the process of arbitration is preferred and the jurisdiction of the arbitrator is to be protected." Local 71, Int'l Bhd. of Teamsters v. Akers Motor Limes, Inc., 582 F.2d 1336, 1341 (4th Cir. 1978), cert. denied, 440 U.S. 929 (1979); accord Columbia Local, Am. Postal Workers Union v. Bolger, 621 F.2d 615, 617 (4th Cir. 1980); United Steelworkers v. Fort Pitt Steel Casting, 598 F.2d 1273, 1282-83 (3d Cir. 1979); Mail Handlers v. United States Postal Serv., 103 L.R.R.M. (BNA) 3107, 3109 (D. Neb. 1978); Bakery Drivers Union v. S.B. Thoinas, Inc., 99 L.R.R.M. (BNA) 2253, 2255-56 (E.D.N.Y. 1978). 
sion of Buffalo Forge. ${ }^{105}$ The difficulty in making a judicial determination that arbitration would not restore the parties to their status quo ante, however, renders such an extension of Buffalo Forge problematic. In addition, there is the danger that in the absence of a clearly delineated standard the decision will be read much too broadly.

\section{The Presumption of Arbitrability: Focusing on the Nature of the Injury Threatened.}

Although it may not be possible to prevent entirely the lower courts from examining the contents of the labor agreement when they are required to determine "arbitrability,"106 such an inquiry can be limited by focusing attention on the nature of the injury threatened, rather than on the conduct giving rise to the petition for injunctive relief. ${ }^{107}$ As previously noted, in cases in which an employer is seeking an mjunction against a striking union, a distinction is easily drawn between the conduct giving rise to the grievance over which the employees are striking and the nature of the injury threatened from continuance of the strike. ${ }^{108}$ The grievance, which may or may not be

105. In his dissent in Buffalo Forge, Justice Stevens noted that "to protect the efficacy of arbitration, any such injunction should require the parties to submit the issue . . . upon an expedited schedule that assures a decision by the arbitrator as soon as practicable. Such stringent conditions would insure that only [actions] in violation of the agreement would be enjoined . . . " Buffalo Forge Co. v. United Steelworkers, 428 U.S. 397, 431 (1976) (Stevens, J., dissenting); see also Gould, On Labor Injunctions Pending Arbitration: Recasting Buffalo Forge, 30 STAN. L. Rev. 533, 541-42 (1977) ("[W]henever a Boys Markets injunction issues, it should be conditioned on the willingness of both parties to accede to expedited arbitration procedures. Under such procedures, the . . . duration of the court's imjunction [is limited] and . . . the role of arbitration [is preserved] as the dispute-settlement mechanism."); cf. United Steelworkers v. Fort Pitt Steel Casting, 598 F.2d 1273, 1282-83 (3d Cir. 1979) (describing how long an injunction should last).

106. "The lynchpin of Buffalo Forge was the Court's finding that the synnpathy strike at issue would not frustrate the arbitration process." Local 71, Int'l Bhd. of Teamsters v. Akers Motor Lines, Inc, 582 F.2d 1336, 1341 (4th Cir. 1978), cert. denied, 440 U.S. 929 (1979). In Dana, the arbitration process would indeed be frustrated; arbitration would be a "hollow formality" if it took place after the election. See UAW v. Dana Corp, 679 F.2d 634, 639 (6th Cir. 1982), reh' 'g en banc granted and opinion vacated, id. at 654 (Aug. 12, 1982).

107. Indeed, the Supreme Court was already broadly interpreting the degree of permissible judicial interference when it handed down the Buffalo Forge decision. In Boys Markets style cases, in which an injunction is granted despite Norris-LaGuardia because to do so would promote the poicy underlying the Act, the arbitrator may subsequently assess the merits of the underlying dispute. But in post-Buffalo Forge cases, the court examines the precise issue to be resolved by the arbitrator and therefore adjudicates, in advance, the primary contract dispute. See Cantor, supra note 30, at 258. The Dana court did decide the primary contract dispute, but only because a determination at any later date would have been ineffectual.

108. The dominant tests among the federal courts of appeals for the denial or issuance of injunctions against employers appear to be considerations of the nature of the injury and the ability of the parties to return to their status quo ante. See Shank, supra note 4, at 918; see, eg., Gateway Coal Co. v. United Mine Workers, 414 U.S. 368, 379 (1974) (strike called to prevent subjecting employees to physical danger); United Steelworkers v. Fort Pitt Steel Casting, 598 F.2d 
arbitrable, is separate and distinct froin the self-help measure that threatens injury to the einployer.

In the Dana situation, however, the conduct giving rise to the grievance is identical to the conduct sought to be enjoined. The UAW was seeking an mjunction preventing the corporation from inaking anti-union statements, the very activity that the union claimed was in violation of the collective bargaining agreenent. Consequently, requiring determination of the arbitrability of the underlying grievance prior to consideration of an injunction creates problems. The determination of arbitrability necessarily involves examination of the merits, but it need not involve a decision on the merits. It is a matter of degree. One way to confine a court's inquiry would be to impose a presumption of arbitrability. ${ }^{109}$ Such a presuniption would allow the federal courts to consider whether the situation is one in which traditional equitable standards warrant injunctive relief, yet would allow courts to avoid a detailed examination of the merits of the dispute. ${ }^{110}$

Focusing on the nature of the injury threatened, rather than on the parties' conduct, will present definitional problems to federal courts trying to determine whether equitable relief is warranted under the Norris-LaGuardia Act. The Act itself describes the equitable standards, and courts have used it as a basis for determining whether to grant injunctions despite the Act's prohibition. The relevant judicial concerns are the following: (1) whether the party seeking injunctive relief has established some likelihood of success on the inerits in the future arbitration hearing; ${ }^{111}$ (2) whether irreparable injury is

1273, 1282 (3d Cir. 1979) (possibility that an uninsured worker would be denied adequate medical care constituted irreparable injury); Local 71, Int'l Bhd. of Teamsters v. Akers Motor Lines, Inc., 582 F.2d 1336, 1343 (4th Cir. 1978) (injunction allowed to prevent employer froin partially liquidating its business because if remaining vehicles and terminals were sold there would be no jobs for reassignment to union's enployees following arbitration), cert. denied, 440 U.S. 929 (1979); Anheuser-Busch, Inc. v. Teamsters Local No. 633, 511 F.2d 1097, 1100 (1st Cir.) (injunction to stop the wearing of tank tops in areas seen by persons touring plant was deemed hardly "the type of injury properly providing a basis for injunctive relief"), cert. denied, 423 U.S. 875 (1975).

109. See supra text accoinpanying notes 62-64.

110. The Supreme Court has imposed a presumption of arbitrability in the past. See, e.g., United Steelworkers v. American Mfg. Co., 363 U.S. 564, 568 (1960) (arbitration clause that, on its face, requires arbitration in given situation will not be construed in detail by court because the question of arbitrability is reserved to the arbitrator); Textile Workers Union v. Lincoln Mills, 353 U.S. 448, 455 (1957) (federal policy favors specific enforcement of agreements to arbitrate grievance disputes on behalf of or against labor organizations).

111. See 29 U.S.C. 8107 (a) (1976). For a case construing this requirement, see, e.g., Dormelly Garment Co. v. Dubinsky, 154 F.2d 38, 41-43 (8th Cir. 1946). The statute's requirenient that "unlawful acts have been threatened and will be committed . . . or have been committed and will be continued" has been interpreted to inean "some likelihood of success on the merits." Lever - Bros. v. International Chem. Workers Union, Local 217, 554 F.2d 115, 120 (4th Cir. 1976). The "likelihood of success on the merits" that must be shown in order to obtain a preliminary imjunc- 
threatened and will occur if no injunction is issued;112 (3) whether the harm to the defending party if an injunction is erroneously issued will be greater than the harm to the complaining party if an injunction is erroneously demied;113 (4) whether the complaining party has "clean hands" - that is, did it attempt to arbitrate before seeking an injunction to compel the defending party to arbitrate; 114 and (5) whether there is no adequate remedy at law - that is, will money damages fail to make the complaining party whole if it subsequently prevails at arbitration.115 Had the district court in Dana presumed arbitrability and focused on these five equitable standards for injunctive rehef, it would have reaehed the same conclusion without having to interpret the substantive provisions of the contract or to usurp the function of the arbitrator.

1. Likelihood of Success. - At first blush, the requirement of "some likelihood of success on the merits" appears just as likely to lead federal courts to contractual interpretation as the requirement that they determine arbitrability. But courts can avoid the inerits of the contract dispute if they adopt the approach propounded by the United States Court of Appeals for the Fourth Circuit in Lever Brothers v. International Chemical Workers Union, Local 217.116 The Lever Brothers court stated that if the party seeking injunctive relief can prove its position sufficiently sound to prevent the arbitration from being futile, then it has met its burden of establishing a likelihood of success on the mer-

tion maintaining the status quo pending arbitration means "not simply some likelihood of success in compelling arbitration but in obtaining the award in aid of which the injunction is sought." Hoh v. Pepsico, Inc., 491 F.2d 556, 561 (2d Cir. 1974) (emergency arbitration by union for mjunctive rehief to prevent shutting down of a plant when collective bargaining agreement contained a provision subjecting all disputes or complaints to arbitration). But see Lever Bros. v. International Chem. Workers Umion, Local 217, 554 F.2d 115, 120 (4th Cir. 1976) ("a plaintiff, without regard to whether he is the employer or the union, seeking to maintain the status quo pending arbitration ... need only establish that the position he will espouse in arbitration is sufficiently sound to prevent arbitration from being a futile endeavor") (quoting Amalgamated Transit Union Div. 1384 v. Greyhound Lines, Inc., 529 F.2d 1073, 1077-78 (9th Cir. 1976), vacated, 429 U.S. 807 (1976) (judgment remanded for further consideration in light of Buffalo Forge Co. v. United Steelworkers, 428 U.S. 397 (1976)), rev'd, 550 F.2d 1237 (9th Cir.), cert. denied, 434 U.S. 837 (1977)).

112. See 29 U.S.C. $\$ 107$ (b) (1976); see also supra note 53 (discussion of the judicial omission of the word "property" from this standard).

113. See 29 U.S.C. \& 107(c) (1976); see, eg., Lauf v. Shinner \& Co., 303 U.S. 323, 330 (1938) (reference to balance of harms).

114. See 29 U.S.C. $\$ 108$ (1976); see, e.g., Boys Markets, Inc. v. Retail Clerks Union, Local 770, 398 U.S. 235, 251-55 (1970) (discussion of atteinpt to arbitrate requirement).

115. See 29 U.S.C. \& 107(d) (1976); see, e.g., Lauf v. Shinner \& Co., 303 U.S. 323,330 (1938) (reference to no adequate remedy at law).

116. 554 F.2d 115 (4th Cir. 1976). 
its. ${ }^{17}$ In Dana, the UAW could have met this burden by presenting to the court the letter containing the neutrality agreenent, ${ }^{118}$ the arbitration clause subjecting all disputes over interpretation and/or application of the terms of the agreement to inandatory arbitration, ${ }^{119}$ and proof of some action that triggered the arbitration and/or neutrality clause. This information would have demonstrated sufficiently that arbitration would not be futile. Sucl a deinonstration would have provided a basis for the court's opinion that there were grounds for believing that the dispute was covered by the arbitration clause and would have left to the arbitrator's judgment the ultimate determinations of whether the dispute was covered and whether the contract had been violated.

2. Irreparable Injury. The fact that the claim made by the party seeking injunctive relief appears to be meritorious is insufficient in itself to warrant the issuance of an injunction. The plaintiff also must demonstrate a need to maintain the status quo pending arbitration. If no substantial harm will result from permitting the acts complained of to continue until arbitration takes place, then traditional equitable standards do not justify injunctive relief. For this reason, Congress and the courts have required the plaintiff to show lie will be irreparably ijured unless injunctive relief is granted. ${ }^{120}$

The federal courts disagree, however, on the concrete meaning of the words "irreparable imjury." One test treats irreparable injury as essentially the equivalent of frustration of the arbitral process. ${ }^{121}$ Another suggested test for irreparable injury is whether the arbitral reinedy for contractual breaches is clearly imadequate under the circumstances, or whether a party's actions render "the arbitral process a hollow formality." 122 A third possible approach is to ascertain

117. Id. at 120.

118. For the text of the neutrality agreement, see Dana, 679 F.2d at 637 . See also supra note 100.

119. For an explanation of the arbitration clause, see Dana, 679 F.2d at 636.

120. See Boys Markets, Inc. v. Retail Clerks Union, Local 770, 398 U.S. 235, 254 (1970); 29 U.S.C. $\& 107$ (1976).

121. Local 71, Int'1 Bhd: of Teamsters v. Akers Motor Lines, Inc., 582 F.2d 1336, 1341 (4th Cir. 1978), cert. denied, 440 U.S. 929 (1979). For examples of what constitutes irreparable injury, compare United Steelworkers v. Fort Pitt Steel Casting, 598 F.2d 1273 (3d Cir. 1979) (threat of irreparable injury found where, in absence of mjunctive relief, employer would cease inaking insurance payments on behalf of employees and hospital and insurance benefits of union menibers would lapse), with Detroit Newspaper Publishers Ass'n v. Detroit Typographical Union No. 18, 471 F.2d 872 (6th Cir.) (no threat of irreparable mjury found when newspaper decided to install new typesetting equipment even though some union members' jobs were threatened), cert. denied, 411 U.S. 967 (1972).

122. Lever Bros. v. International Chem. Workers Union, Local 217, 554 F.2d 115, 123 (4th Cir. 1976). If after prevailing in arbitration a union would be faced with a fait accompli by the 
whether failure to issue the preliminary injunction to protect a right would amount to a "destruction of that right" if the issue were subsequently resolved at arbitration in favor of the party seeking injunctive relief. 123

Each of these approaches, while different in form, is essentially the same in substance. The underlying concern in each is whether subsequent arbitration will be able to return the parties substantially to their status quo ante. If it cannot, then certainly the arbitral process will be "frustrated" due to a lack of reinedial force. Having been irreparably injured, the plaimtiff would be warranted in viewing the other side's promise to arbitrate as "illusory." 124 Therefore, the appropriate test for irreparable harm is whether the questionable conduct must be enjoined because the available arbitral process could not restore the status quo ante in an acceptable form if that conduct was later found violative of contract rights. ${ }^{125}$ In Dana, application of this threshold test would have resulted in the same conclusion that the district court reached after lengthy consideration of the substantive provisions of the neutrality agreeinent. ${ }^{126}$

3. No Adequate Remedy at Law and Unclean Hands. The "no adequate remedy at law" and "unclean hands" considerations reinforce the conclusion that injunctive relief was warranted in Dana. Requiring the plaimtiff to prove irreparable harm necessarily requires the court to find that the plaimtiff has no adequate remedy at law. If money damages would inake the plaintiff whole then there has been no irreparable injury. Monetary relief would certainly be inadequate in Dana, as the lost representation election could not thereby be recovered. With regard to the "clean hands" requirement, certainly the UAW had exhausted all reasonable inethods of compelling arbitration before it sought redress in the courts. On three separate occasions the union

company, then the arbitration would undoubtedly be "but an empty victory" for the union. Local 71, Int'l Bhd. of Teamsters v. Akers Motor Lines, Inc., 582 F.2d 1336, 1340-41 (4th Cir. 1978) (quoting Lever Bros, 554 F.2d at 122), cert. denied, 440 U.S. 929 (1979). In such a case the irreparable character of the injury is evident.

123. See Gallagher, Injunctions Restraining Employers Pending Arbitration-Equity and Labor Policy, 82 Dick. L. Rev. 487, 499 (1978).

124. Cf. Shank, supra note 4, at 911 (citing Western Publishing Co. v. Local 254, Graphic Arts Int'1 Union, 522 F.2d 530, 533 (7th Cir.) (caveat: this case involved a request for damages rather than injunctive relief), cert. denied, 423 U.S. 1088 (1976)).

125. Were the offending party later to repeat the actions complained of in the first proceeding, the complaining party would have no reason to expect that its chances for successfully halting the action had improved; thus it would be unable to protect the right at stake. This would surely threaten destruction of that right.

126. See UAW v. Dana Corp., 679 F.2d 634, 639 (6th Cir. 1982), ref'g en banc granted and opinion vacated, id at 654 (Aug. 12, 1982). 
attempted to arbitrate the grievance and was met with postponement, promises to cease and desist, and, finally, silence. The UAW was not guilty of either bypassing or impeding the arbitral process in petitioning the court for an order to compel arbitration.

4. Balance of Harms. The final consideration is that of balancing the potential harm to the plaintiff if an injunction is denied against the harm to the defendant if the injunction is granted. In order for a court to reach this stage, the plaintiff must already have shown that it will be irreparably injured if injunctive relief is not granted. The defendant must at the very least establish that it will also be irreparably injured. If the defendant can meet this burden of proof, then the court nuust consider the nature of both irreparable injuries to determine which is more serious. To balance these threats of injury, courts should consider the policy behind the labor laws. ${ }^{127}$

\section{E. Rebuttal of the Presumption of Arbitrability.}

The use of a presumption of arbitrability to enable the courts to focus on equitable standards for injunctive relief is not novel. The Supreme Court employed a presumption of arbitrability in the Steelworkers Trilogy. ${ }^{128}$ Suggesting that the Suprene Court clearly outline such a presumption and its mode of operation, therefore, amounts to advocating a return to and clarification of a previous position. ${ }^{129}$

This note suggests that the presumption need apply only in cases in which the conduct sought to be enjoined was the sane conduct

127. In Dana, denial of the injunction would have cost the UAW any chance of being elected the employees' bargaining representative after six weeks of campaigning. No subsequent arbitration award could win back the election or restore the employees' confidence in the UAW's ability to effectively represent them in their disputes with the Dana Corporation. Future campaign efforts were thus also frustrated; as already noted, this constituted irreparable injury. Dana, on the other hand, may have suffered soine injury in the form of restraint on free speech and press; however, subsequent arbitration could have restored Dana to its status quo ante. The injunction merely prohibited Dana from further speech and press directed at the UAW's organizational efforts until an arbitrator could decide whether such speech and press violated the neutrality clause. Upon a favorable finding, Dana would have been free for any unexpired portion of the period preceding this election, and in any other organizational efforts on the part of the UAW, to make similar statements about the UAW. In sum, no harm resulted to Dana from the district court's issuance of temporary injunctive relief pending arbitration because the status quo was not affected.

128. See United Steelworkers v. Warrior \& Gulf Navigation Co., 363 U.S. 574, 582-83 (1960).

129. The desirability of this approach is demonstrated by its attempted use at the court of appeals level. Cf. Lever Bros. v. International Chem. Workers Union, Local 217, 554 F.2d 115, 119 (4th Cir. 1976) (no express exclusion from the arbitration clause and clause reasonably suscep-tible of an interpretation that would incude it) (citing United Steelworkers v. Warrior \& Gulf Navigation Co., 363 U.S. 574, 582-83 (1960)). 
claimed to be violative of the collective bargaining agreement. 130 Furthermore, the presumption would be made rebuttable. This factual situation is most likely to lead courts into the merits of the contract dispute: An exainination of Dana demonstrates the operation of this proposed rebuttable presumption. Once the UAW triggered the presumption of arbitrability, the burden should have been placed on Dana to rebut the inference raised by the UAW that a contract violation had occurred and that the UAW would most likely prevail on the merits in any subsequent arbitration. In Lever Brothers v. International Chemical Workers Union, Local 217, the Court of Appeals for the Fourth Circuit set up a two-part test to determine whether a presumption of arbitrability had been rebutted: the defending party must not only demonstrate that the particular type of grievance being disputed was specifically excluded from the arbitration clause, but also that the arbitration clause is not reasonably susceptible of an interpretation that covers the particular type of grievance being disputed. ${ }^{131}$ Clearly, in Dana, the company could not have rebutted the inferences of arbitrability and likelihood of UAW's success on the inerits. The contract contamed no clause specifically excluding the neutrahty agreement from the reach of the arbitration clause. Furthermore, the arbitration clause itself was susceptible to an interpretation that covered the grievance. The language of the clause was all-inclusive. ${ }^{132}$

Once a district court determines that the defending party has not rebutted the presumption of arbitrability, it may turn to traditional equitable standards for injunctive rehef. As noted, the first of these standards - the likelihood of success on the merits-will almost always be satisfied if the defending party has failed to rebut the presumption of arbitrability. The next step is to determine whether irreparable injury is threatened because subsequent arbitration could not return the parties to their status quo ante. If the defending party then cannot demonstrate that it is threatened with nore serious injury than the injury threatened to the complaining party, the complaining party should be entitled to injunctive relief if it has not itself been guilty of frustrating the arbitral process.

130. It is this characteristic of Dana that led the trial coun into a detailed examination of the merits of the dispute.

131. See 554 F.2d at 119. Lever Brothers presents a case of "not reasonably susceptible"; Warrior \& Gulf presents a case of specific exclusion.

132. Cf. UAW v. Dana Corp., 679 F.2d 634, 636 (6th Cir. 1982) (clause provided for arbitration "should any trouble or controversy arise with respect to the employees within the unit as between the company and union"), reh'g en bane granted and opinion vacated, id. at 654 (Aug. 12, 1982). 


\section{CONCLUSION}

The district court in Dana quite properly awarded injunctive relief to the UAW. By focusing its attention on the determination of arbitrability, however, the court effectively decided the case on the merits. The court's infringement upon the arbitrator's function was entirely unnecessary and improper. The court could have reached the same result, yet could have left the ultimate determination of whether the contract had been violated to the arbitrator. When considered together, the mandatory arbitration clause, Dana's refusal to arbitrate, the neutrality agreement, and the examples of the statements made by the Dana official were sufficient to establish a prima facie case of contract violation.

In most cases, a cursory examination of the collective bargaining agreement will be sufficient to permit the court to determine that the grievance inay be arbitrable. Doubts should be resolved in favor of arbitrability. Once the issue of arbitrability is decided, the courts inay then turn their attention to traditional equitable standards to determine whether the inoving party will suffer harm that can properly be characterized as irreparable if the injunction is demed and whether the opposing party will suffer greater harm if the injunction is granted. The Supreme Court should adopt a rebuttable presumption of arbitrability at its earliest opportumity, to prevent courts froln continumg to infringe upon the arbitrator's role and upon the parties' right to contract for an exclusive method of dispute settlement. 